\title{
Depressive symptoms and neurotrophin levels in ostomy patients
}

\author{
Sintomas depressivos e níveis de neurotrofina em pacientes com ostomia
}

Daniela Vicente Bavaresc01,2, Mágada Tessmann Schwalm³, Luciano Kurtz Jornada', Luiz Felipe Andrade Quadros', Bruna Simon ${ }^{3}$, Luciane Bisognin Ceretta ${ }^{4}$, Karina Cardoso Gulbis Zimmermann³, Maria Inês da Rosa², Samira Silva Valvassori ${ }^{1}$

\section{ABSTRACT}

Objective: The aim of the present study was to investigate the depressive symptoms and changes in neurotrophins (BDNF, NGF, NT-3), and cortisol levels in serum of peripheral blood from ostomy patients compared to healthy control group. Methods: We evaluated ostomy $(n=29)$ and healthy control $(n=30)$ patients. The neurotrophin (BDNF, NGF, NT-3), and cortisol levels were assessed by ELISA in serum of peripheral blood. Depressive symptoms were defined based on the Hamilton Depression Rating Scale (HDRS), and major depression disorder was based on clinical interviews and was confirmed with the Structured Clinical Interview for DSM-IV Axis I Disorders (SCID-I). Results: The results showed a significant decrease in BDNF levels and, a significant increase in NT-3 levels in serum of peripheral blood from ostomy patients when compared to healthy controls. The levels of NGF and cortisol showed no significant differences between groups. The depressive symptom evaluations by HDRS demonstrated a significant increase in ostomy patients when compared to healthy controls. The major depression disorder diagnosis by SCID-I showed no significant difference between groups. Conclusion: Our results suggest ostomy triggers significant depressive symptoms and alterations in neurotrophins levels in serum of peripheral blood samples collected from these patients.

\section{RESUMO}

Objetivo: $O$ objetivo do presente estudo foi investigar os sintomas depressivos e alterações nos níveis de neurotrofinas (BDNF, NGF, NT-3) e cortisol em soro de sangue periférico de pacientes ostomizados em comparação com grupo controle saudável. Métodos: Foram avaliados pacientes ostomizados $(n=29)$ e controles saudáveis $(n=30)$. Os níveis de neurotrofinas (BDNF, NGF, NT-3) e cortisol foram avaliados por kit ELISA em soro de sangue periférico. Os sintomas depressivos foram definidos com base na Hamilton Depression Rating Scale

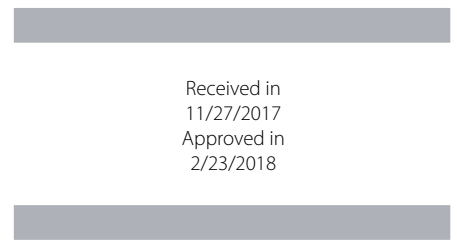

DOI: $10.1590 / 0047-2085000000203$
1 Universidade do Extremo Sul Catarinense (Unesc), Unidade Acadêmica de Ciências da Saúde, Pós-Graduação em Ciências da Saúde, Laboratório de Sinalização Neural e Psicofarmacologia, Criciúma, SC, Brazil.

2 Universidade do Extremo Sul Catarinense (Unesc), Laboratório de Epidemiologia, Criciúma, SC, Brazil; Unesc, Programa de Pós-Graduação em Saúde Coletiva, Programa de Pós-Graduação em Ciências da Saúde, Criciúma, SC, Brazil.

3 Universidade do Extremo Sul Catarinense (Unesc), Unidade Acadêmica de Ciências da Saúde, Curso de Enfermagem, Criciúma, SC, Brazil. 4 Universidade do Extremo Sul Catarinense (Unesc), Unidade Acadêmica de Ciências da Saúde, Programa de Pós-Graduação em Saúde Coletiva, Laboratório de Saúde Coletiva, Criciúma, SC, Brazil.

\section{Address for correspondence: Samira Silva Valvassori}

Laboratório de Sinalização Neural e Psicofarmacologia, Programa de Pós-Graduação em Ciências da Saúde, Unidade Acadêmica de Ciências da Saúde, Universidade do Extremo Sul Catarinense

Av. Universitária, 1105, Universitário

88806-000 - Criciúma, SC, Brasil

Telephone: 55 (48) 3431-2792

E-mail: samiravalvassori@unesc.net 


\section{Palavras-chave}

Ostomia, BDNF, NGF, NT-3, depressão.
(HDRS), e o transtorno depressivo maior foi baseado em entrevistas clínicas e confirmado pela Structured Clinical Interview for DSM-IV Axis I Disorders (SCID-I). Resultados: Os resultados mostraram diminuição significativa nos níveis de BDNF e aumento significativo nos níveis de NT-3 no soro de sangue periférico de pacientes ostomizados quando comparados com controles saudáveis. Os níveis de NGF e cortisol não apresentaram diferenças significativas entre os grupos. As avaliações dos sintomas depressivos pela HDRS demonstraram aumento significativo em pacientes ostomizados quando comparados com controles saudáveis. $\mathrm{O}$ diagnóstico de transtorno depressivo maior pela SCID-I não mostrou diferença significativa entre os grupos. Conclusão: Nossos resultados sugerem que a ostomia desencadeia sintomas depressivos significativos e alterações nos níveis de neurotrofinas no soro de sangue periférico coletadas desses pacientes

\section{INTRODUCTION}

Ostomy is a surgically created opening between an internal organ and the body surface, often created as an intestinal' or colon ${ }^{2}$ surgical part in cases where the body has no natural possibility of releasing intestinal waste. Also, it is necessary to treat complicated abdominal problems or to allow the healing of surgical site'. The ostomy is classified into some types, based on patients' conditions, such as Colostomy, Temporary Colostomy, Permanent Colostomy, Sigmoid or Ascending Colostomy, Transverse Colostomy, Loop Colostomy, lleostomy, lleoanal Reservoir (J-Pouch), Continent lleostomy (Kock Pouch), Urostomy, Continent Urostomy, Indiana Pouch, Neobladder Orthotopic ${ }^{3}$. Each one specifically used, while a urostomy can be formed for a bladder cancer or interstitial cystitis ${ }^{2}$, the ileostomy or colostomy is indicated for recovering more sick or operated parts induced by intestinal inflammatory or malignant diseases, such as: colorectal cancer, diverticular disease, intestinal infarction, severe trauma and also in complex anal complications ${ }^{4}$.

The main ostomy patient issues after discharge are: peristomal skin irritation, pouch leakage, odor, reduction of previously appreciated activities and depression or anxiety $^{5-7}$. In clinical trials, it is possible to see that stoma use significantly reduces the quality of life (QOL), and presenting depressive symptoms after the stoma surgery according to ostomy site ${ }^{6,8}$. The overall prevalence of depression was $24 \%$ among rectal cancer survivors with the highest prevalence among those with a previous permanent ostomy $(31 \%)^{7}$.

Ostomy patients can have negative attitudes toward themselves and should have postoperative psychological support ${ }^{9}$. Thus needing a better understanding of these ostomy-related complications to improve coping strategies; in addition, abnormal psychological states may have consequences for self-care and facilitate the several comorbidities occurrence in these patients ${ }^{6}$. Depressive mood was accompanied by several physiological changes ${ }^{10}$. In the present study, we focused on the possible changes in cortisol and neurotrophins levels, and this biomarker relation with depression and ostomy $y^{11,12}$. This marker relationship in ostomy patients is still poorly described.

The hypothalamic-pituitary-adrenal axis (HPA) is the central modulator of mammalian neuroendocrine stress response systems, and as such has been important in psychiatric disorders studies ${ }^{13-16}$. In stress situations, the adrenal gland increases the cortisol production. The increased cortisol release, due to long-term stressful situation exposure, seems to play an important role in the depressive symptoms neurobiology ${ }^{17}$.

Neurotrophins are growth factors that promote the neuronal survival, development and function, acting in the apoptosis prevention, among the neurotrophins are brainderived neurotrophic factor (BDNF), nerve growth factor (NGF) and neurotrophin-3 (NT-3) ${ }^{18}$. The main neurotrophin described in the depression neurobiology is BDNF, either by controlling neuronal number or in the dendritic growth ${ }^{19}$. Studies suggest that BDNF deregulation occurs under chronic-stress conditions and depression ${ }^{20}$. In previous studies, with lower peripheral BDNF levels in depressed patients, BDNF has been considered an important biomarker for Major Depression Disorder (MDD), and antidepressants would be able to reverse this decrease $\mathrm{e}^{21-23}$.

In this context, the present study was aimed at investigating the neurotrophins (BDNF, NGF, NT-3) and cortisol levels changes in peripheral blood taken from ostomy patients when compared to those collected from subjects in a healthy control group.

\section{METHODS}

\section{Patients}

The present study was approved by the Ethics Committee of the Universidade do Extremo Sul Catarinense (Unesc), protocol number: 787.325, in accordance with the recommendations of the Declaration of Helsinki and the resolution no 196/96 of the National Health Council on research involving humans. The study evaluated 29 ostomy patients and 30 healthy control patients, recruited from among those enrolled in the 
Nursing Clinic of the Unesc, located in the city of Criciúma, Brazil. Patients were only included in the study after signing the Subject Information and Consent Form.

\section{Study design}

We conducted a case-control study. A total of 29 consecutives patients over 18 years old with ostomy were selected as cases. The control group was 30 healthy patients, from of the same Nursing Clinic.

Structured questionnaires were administered by the same manner in cases and controls. Information about demographic factors and lifestyle was obtained. Psychiatric diagnoses for major depressive disorder were used in the Structured Clinical Interview for the DSM-IV Axis I Disorders (SCID-I) chapter mood disorders. Depressive symptoms were assessed using the Hamilton Depression Rating Scale (HDRS) patients who scored more than eight were considered cutoff score for presence of mood and depressive symptoms.

\section{Sample collection}

From each subject, $10 \mathrm{ml}$ of peripheral blood were drawn by venipuncture into a vacuum tube. Immediately, the blood was centrifuged at 3,000x $\mathrm{g}$ for $10 \mathrm{~min}$, and the serum was stored at $-80^{\circ} \mathrm{C}$ for subsequent assay.

\section{BDNF, NGF, and NT-3 level measurement}

Biochemical analyses were in serum of peripheral from ostomy patients and healthy control patients. For analyzing the neurotrophic factors, the serum were diluted in phosphatebuffered solution (PBS) with $1 \mathrm{mMphenylmethylsulfonyl}$ fluoride (PMSF) and $1 \mathrm{mM}$ ethylene glycolbis (2-aminoethyl ether)- $N, N_{,} N^{\prime} N^{\prime}$-tetraacetic acid (EGTA). The diluted blood serum were centrifuged at 10,000x $\mathrm{g}$ for $20 \mathrm{~min}$, and the supernatants were collected for neurotrophic factor level quantification. The BDNF, NGF, and NT-3 levels in serum were measured by sandwich enzyme-linked immunosorbent assay using commercial ELISA kits (96-well plate) according to manufacturer's instructions. NGF and BDNF levels were assessed with a kit from Chemicon (USA) (NGF catalog number: ABIN365470; BDNF catalog number: KE00096), and NT-3 levels were assessed with a kit from Biosensis (USA) (NT-3 catalog number: BEK-2221-2P). Total protein was measured by Lowry et al. ${ }^{24}$ method using bovine serum albumin as a standard.

\section{Measurement of cortisol levels}

For the quantitative measurement of Cortisol in serum of peripheral blood was diluted in phosphate-buffered solution (PBS) with $1 \mathrm{mMphenylmethylsulfonyl} \mathrm{fluoride} \mathrm{(PMSF)} \mathrm{and}$ $1 \mathrm{mM}$ ethylene glycolbis (2-aminoethyl ether)-N,N, $\mathrm{N}^{\prime} \mathrm{N}^{\prime}$ tetraacetic acid (EGTA). The dilution were centrifuged at 10,000x $\mathrm{g}$ for $20 \mathrm{~min}$, and the supernatants were collected for quantification of the cortisol levels. The Cortisol levels in serum were measured by sandwich enzyme-linked immunosorbent assay using commercial kits according to the manufacturer's instructions from Parameter ${ }^{\mathrm{TM}}$ (Catalog Number KGE008B). Total protein was measured by Lowry et al. ${ }^{24}$ method using bovine serum albumin as a standard.

\section{Statistics}

Data were analyzed with Statistical Package for Social Sciences (SPSS) software, version 22.0 (IBM Corporation, Armonk, NY, USA). Normality distribution was examined by Shapiro-Wilk test. Biochemical test showed normal distribution in the statistical test. To identify the differences between groups (ostomy versus healthy control patients) of biochemical variables we used Student $t$ test independent by groups. For the non-parametric variable used the Wilcoxon test. For patient demographic factors and lifestyle characteristics, we used Fisher's exact test. P values of less than 0.05 for associations were considered to indicate statistical significance

\section{RESULTS}

Table 1 shows ostomy patient characteristics when compared to healthy control, the data indicated groups were homogeneous regarding age, gender, smoking, ethnicity, alcoholic, other diseases, and menopause and hormone replacement therapy in the women. The variables that had a significant difference between the groups were: marital status, occupation, and religion. However, these variables do not interfere with the biochemical parameters. Regarding the depressive symptoms evaluations by HDRS and the depressive disorder diagnosis by SCID-I, only HDRS had a significant difference between the groups. It was found an increase in the HDRS $(p=0.027)$ score was observed in ostomy patients when compared to healthy controls.

Table 2 describes the ostomy patient characteristics. The ostomy time median was 26 months and interquartile range (IQL) 11.0-62.5. The most predominant type of ostomy was colostomy ( $n=23,79.3 \%) .22$ patients had neoplasia (75.8\%) as the leading cause of ostomy, followed by diverticulitis ( $\mathrm{n}$ $=3,10.3 \%$ ). Variable reversal attempts indicated 25 patients (86.2\%) not tried reversing the ostomy. 22 patients (75.9\%) reported to used one piece. 17 patients (58.6.7\%) reports have no skin complication. The most predominant of patients do not have complications due to ostomy $(n=13,42.9 \%)$.

Table 3 describes the biochemistry parameters dichotomized from the general average. Biochemical assessments are specifically described below in graph form. Figure 1 shows neurotrophins (BDNF $[A], N T-3$ [B], and NGF $[C]$ ) parameters. It was found a decrease of BDNF ( $t=11.076$, $\mathrm{df}=58, \mathrm{p}<0.001)$ (Figure $1 \mathrm{~A})$, and increase of NT-3 ( $\mathrm{t}=$ -20.006, $d f=58, p<0.001$ ) (Figure 1B) levels in serum from ostomy patients compared to controls. Figure 2 showed the cortisol results. Between the patient groups, no significant differences were found. 
Table 1. Characteristics of the patients

\begin{tabular}{|c|c|c|c|}
\hline \multirow{2}{*}{ Variables } & \multicolumn{3}{|c|}{ Patients } \\
\hline & Ostomy $(n=29)$ & Control $(n=30)$ & p-value \\
\hline \multicolumn{4}{|l|}{ Gender } \\
\hline Male, n (\%) & $10(34.5)$ & $5(16.7)$ & $0.116^{\mathrm{a}}$ \\
\hline Female, n (\%) & $19(65.5)$ & $25(83.3)$ & \\
\hline Age, mean $\pm S D$ & $58,52( \pm 18.3)$ & $57.30( \pm 12.9)$ & $0.696^{\mathrm{b}}$ \\
\hline \multicolumn{3}{|l|}{ Ethnicity } & $0.0568^{c}$ \\
\hline German, n (\%) & $8(27.6)$ & $2(6.7)$ & \\
\hline Italian, n (\%) & $10(34.5)$ & $6(20.0)$ & \\
\hline Polish, $n$ & $1(3.4)$ & $2(6.7)$ & \\
\hline Afro, n (\%) & $1(3.4)$ & $2(6.7)$ & \\
\hline Other, $\mathrm{n}(\%)$ & $9(31.0)$ & $18(60.0)$ & \\
\hline \multicolumn{3}{|l|}{ Marital status } & $0.015^{* c}$ \\
\hline Single, $n(\%)$ & $3(10.3)$ & $1(3.3)$ & \\
\hline Married, $\mathrm{n}(\%)$ & $11(37.9)$ & $20(66.7)$ & \\
\hline Widowed, n (\%) & $6(20.7)$ & $8(26.7)$ & \\
\hline Other, $\mathrm{n}(\%)$ & $9(31.0)$ & $1(3.3)$ & \\
\hline \multicolumn{3}{|l|}{ Occupation } & $0.0012^{* c}$ \\
\hline Housewife, n (\%) & $2(6.9)$ & $7(23.3)$ & \\
\hline Retired, $\mathrm{n}(\%)$ & $16(55.2)$ & $13(43.3)$ & \\
\hline Disease aid, n (\%) & $8(27.6)$ & & \\
\hline Other, $\mathrm{n}(\%)$ & $3(10.3)$ & $10(33.3)$ & \\
\hline \multicolumn{4}{|l|}{ Smoker } \\
\hline Yes, n (\%) & $5(17.2)$ & $4(13.3)$ & $0.676^{a}$ \\
\hline No, $n(\%)$ & $24(82.8)$ & $26(86.7)$ & \\
\hline \multicolumn{3}{|l|}{ Alcoholic } & $0.980^{\mathrm{a}}$ \\
\hline Yes, n (\%) & $1(3.4)$ & $1(3.3)$ & \\
\hline No, n (\%) & $28(96.6)$ & $29(96.7)$ & \\
\hline \multicolumn{3}{|l|}{ Religion } & $0.019^{* c}$ \\
\hline Catholic, n (\%) & $22(75.9)$ & $13(43.3)$ & \\
\hline Evangelical, n (\%) & $6(20.7)$ & $16(53.3)$ & \\
\hline Spiritist, n (\%) & $1(3.4)$ & $1(3.3)$ & \\
\hline \multicolumn{3}{|l|}{ Sexual activity } & $0.051^{\mathrm{a}}$ \\
\hline Yes, n (\%) & $11(37.9)$ & $19(63.3)$ & \\
\hline No, $n(\%)$ & $18(62.1)$ & $11(36.7)$ & \\
\hline \multicolumn{3}{|l|}{ Recreation } & $0.514^{a}$ \\
\hline Yes, n (\%) & $19(65.5)$ & $22(73.3)$ & \\
\hline No, $n(\%)$ & $10(34.5)$ & $8(26.7)$ & \\
\hline \multicolumn{3}{|l|}{ Other diseases } & $0.642^{c}$ \\
\hline Systemic arterial hypertension, $\mathrm{n}(\%)$ & $8(27.6)$ & $5(16.7)$ & \\
\hline Diabetes mellitus, $\mathrm{n}(\%)$ & & $1(3.3)$ & \\
\hline Pneumopathies, $\mathrm{n}(\%)$ & $1(3.4)$ & $1(3.3)$ & \\
\hline Rheumatopathies, $\mathrm{n}(\%)$ & $2(6.9)$ & $2(6.7)$ & \\
\hline Other, n (\%) & $4(13.8)$ & $4(13.3)$ & \\
\hline Systemic arterial hypertension and diabetes mellitus, $\mathrm{n}(\%)$ & $2(6.9)$ & $15(50.0)$ & \\
\hline \multicolumn{4}{|l|}{ Without comorbidities, $n(\%)$} \\
\hline & $12(41.4)$ & $2(6.7)$ & \\
\hline \multicolumn{3}{|l|}{ Menopause } & $0.807^{\mathrm{a}}$ \\
\hline Yes, n (\%) & $11(37.9)$ & $13(43.3)$ & \\
\hline No, $n(\%)$ & $8(27.6)$ & $11(36.7)$ & \\
\hline Not applicable, $n(\%)$ & $10(34.5)$ & $5(20.0)$ & \\
\hline \multicolumn{3}{|l|}{ Hormone replacement therapy } & $0.416^{\mathrm{a}}$ \\
\hline Yes, $n(\%)$ & $2(6.9)$ & $1(3.3)$ & \\
\hline No, $n(\%)$ & $17(58.6)$ & $23(76.7)$ & \\
\hline Not applicable, n (\%) & $10(34.5)$ & $5(20.0)$ & \\
\hline \multicolumn{4}{|l|}{ HDRS } \\
\hline 8 or more, $\mathrm{n}(\%)$ & $17(58.62)$ & $9(30.00)$ & $0.027^{* a}$ \\
\hline Up to $7, \mathrm{n}(\%)$ & $12(41.38)$ & $21(70.00)$ & \\
\hline \multicolumn{4}{|l|}{ SCID MD } \\
\hline Positive, $n(\%)$ & $5(18.5)$ & $2(6.7)$ & $0.170^{\mathrm{a}}$ \\
\hline Negative, $\mathrm{n}(\%)$ & $22(81.5)$ & $28(93.3)$ & \\
\hline
\end{tabular}

SCID-I/MD: Structured Clinical Interview for the DSM-IV Axis I Disorders for Major Depression; HDRS: Hamilton Depression Rating Scale; SD: standard deviation. Datas are expressed as \% of patients. * Differences between ostomy versus control patients, $\mathrm{P} \leq 0.05$ were considered to be statistical significant. ${ }^{\circ}$ Chi-square test. ${ }^{b}$ Independent-samples $t$ test, data are expressed as mean \pm SD. ${ }^{\circ}$ Fisher's exact test. 
Table 2. Characteristics of the ostomy patients $(n=29)$

\begin{tabular}{|c|c|}
\hline \multicolumn{2}{|c|}{ Variables } \\
\hline Ostomy time (months), MDN (IQR) & $26.0(11.0-62.5)$ \\
\hline \multicolumn{2}{|l|}{ Type of ostomy } \\
\hline Colostomy, n (\%) & $23(79.3)$ \\
\hline Ileostomy, n (\%) & $4(13.3)$ \\
\hline Urostomy, n (\%) & $1(3.3)$ \\
\hline Colostomy + urostomy, n (\%) & $1(3.3)$ \\
\hline \multicolumn{2}{|l|}{ Cause of ostomy } \\
\hline Diverticulitis, n (\%) & $3(10.3)$ \\
\hline Neoplasia, n (\%) & $23(75.8)$ \\
\hline Abscess anal, n (\%) & $1(3.4)$ \\
\hline Drilling recto sigmoid, $n$ (\%) & $1(3.4)$ \\
\hline 0ther functional bowel disorders, $\mathrm{n}(\%)$ & $1(3.4)$ \\
\hline Sigmoid colon, n (\%) & $1(3.4)$ \\
\hline \multicolumn{2}{|l|}{ Type of ostomy pouch } \\
\hline One piece, n (\%) & $22(75.9)$ \\
\hline Two pieces, n (\%) & $7(24.1)$ \\
\hline \multicolumn{2}{|l|}{ Reversal attempts } \\
\hline Yes, n (\%) & $4(13.8)$ \\
\hline No, n (\%) & $25(86.2)$ \\
\hline \multicolumn{2}{|l|}{ Skin lesions } \\
\hline Yes, n (\%) & $12(41.4)$ \\
\hline No, $n(\%)$ & $17(58.6)$ \\
\hline \multicolumn{2}{|l|}{ Change in life habits after ostomy } \\
\hline Yes, n (\%) & $22(75.9)$ \\
\hline No, $n(\%)$ & $7(24.1)$ \\
\hline \multicolumn{2}{|l|}{ Change of clothes after ostomy } \\
\hline Yes, n (\%) & $16(55.2)$ \\
\hline No, n (\%) & $13(44.8)$ \\
\hline \multicolumn{2}{|l|}{ Complications of ostomy } \\
\hline Dermatitis, n (\%) & $3(10.7)$ \\
\hline Flat stoma, n (\%) & $1(3.6)$ \\
\hline Hernia, n (\%) & $7(25.0)$ \\
\hline Fistula, n (\%) & $2(7.1)$ \\
\hline Prolapse, n (\%) & $1(3.6)$ \\
\hline 0thers, n (\%) & $2(7.1)$ \\
\hline Hassle free, n (\%) & $13(42.9)$ \\
\hline \multicolumn{2}{|l|}{ Presence of diarrhoea } \\
\hline Yes, n (\%) & $6(20.7)$ \\
\hline No, n (\%) & $23(79.3)$ \\
\hline \multicolumn{2}{|l|}{ Change of feeding after ostomy } \\
\hline Yes, n (\%) & $17(58.6)$ \\
\hline No, n (\%) & $12(41.4)$ \\
\hline \multicolumn{2}{|l|}{ Make use of food supplements } \\
\hline Yes, n (\%) & $9(31.0)$ \\
\hline No, n (\%) & $20(69.0)$ \\
\hline
\end{tabular}

MDN: median; IQR: interquartile range

Table 3. Biochemistry parameters

\begin{tabular}{lccc}
\hline \multirow{2}{*}{ Variables } & \multicolumn{3}{c}{ Patients } \\
\cline { 2 - 4 } & Ostomy $(\mathrm{n}=29)$ & Control $(\mathrm{n}=30)$ & $\mathrm{p}$-value \\
\hline BDNF, mean \pm SD & $0.58( \pm 0.09)$ & $0.84( \pm 0.088)$ & $<0.001^{*}$ \\
NT-3, mean \pm SD & $403.43( \pm 60.32)$ & $175.20( \pm 15,75)$ & $<0.001^{*}$ \\
NGF, mean \pm SD & $271.67( \pm 76.88)$ & $257.20( \pm 76.88)$ & 0.873 \\
Cortisol, mean \pm SD & $18.68( \pm 7.91)$ & $16.42( \pm 6,22)$ & 0.222 \\
\hline
\end{tabular}

SD: standard deviation. * Differences between ostomy versus control patients. $p \leq 0.05$ were considered to be statistical significant from $T$ test.
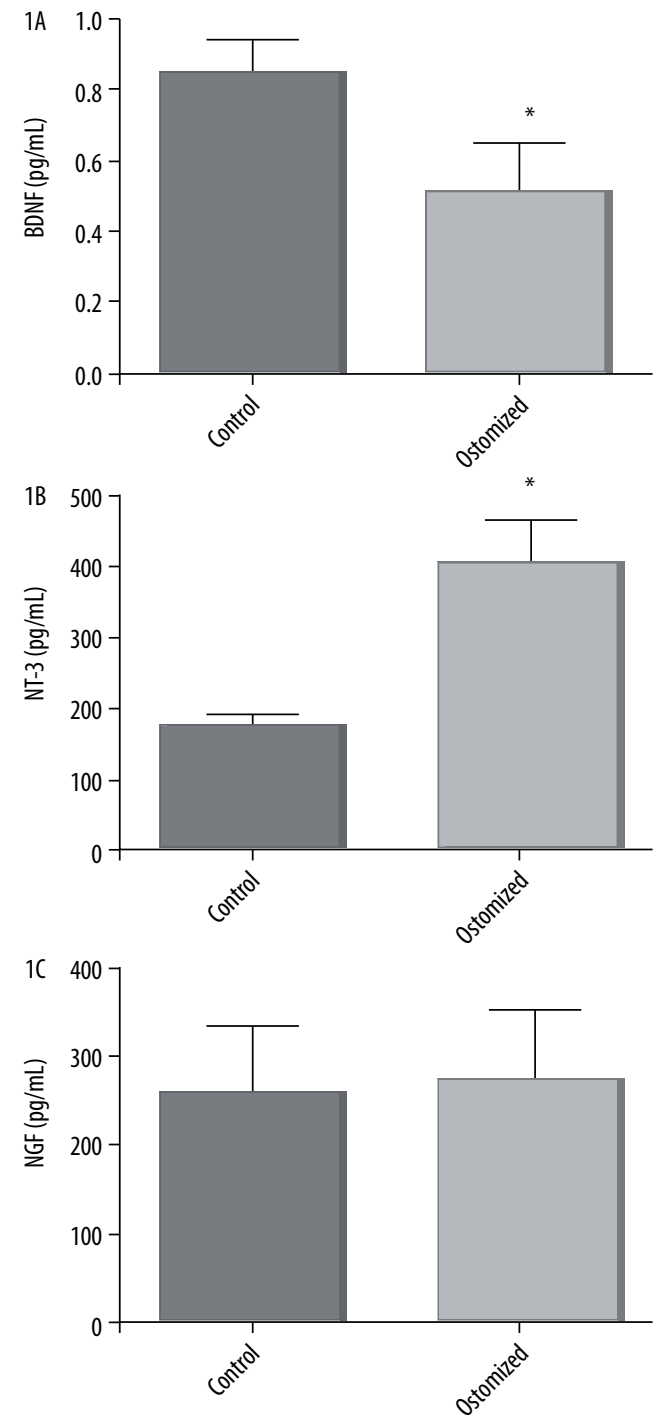

Figure 1. Neurotrophins in serum from ostomy patients compared to health controls. brain-derived neurotrophic factor (BDNF) (A), neurotrophin-3 (NT-3) (B), and nerve growth factor (NGF) (C). The results are expressed as the mean + SD. * Differences between ostomy patients versus health controls. $\mathrm{p} \leq 0.05$ were considered to be statistical significant from $T$ test.

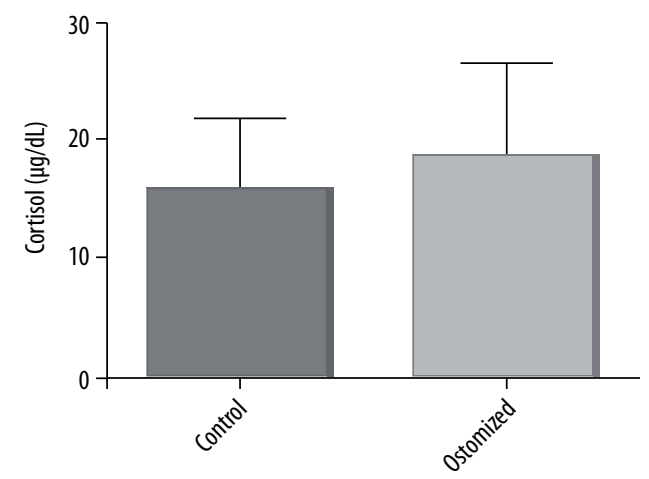

Figure 2. Cortisol level in serum from ostomy patients compared to health controls. The results are expressed as the mean + SD. * Differences between ostomy patients versus health controls. $\mathrm{p} \leq 0.05$ were considered to be statistical significant from $T$ test. 


\section{DISCUSSION}

The investigation of depression, peripheral neurotrophic and cortisol parameters in ostomy patients is still poorly described. This is the first study to provide evidence of a significant BDNF decrease and NT-3 increase in the serum from ostomy patients, when compared to control group. These alterations were associated with psychological and social complications.

In addition, the data showed an increase only in the HDRS, which is a scale for measuring the depressive symptoms levels, the SCID-I instrument is already used for diagnosing psychiatric disorders. Thus, ostomy patients did not have a MDD diagnosis, but presented a depressive symptoms improvement when compared to healthy controls ${ }^{25}$.

The main ostomy patient issues after discharge are: peristomal skin irritation, pouch leakage, odor, reduction of previously appreciated activities and depression or anxiety ${ }^{5}$. In clinical trials, it is possible to see that stoma use significantly reduces the $\mathrm{QOL}$, and presenting depressive symptoms after the stoma surgery according to ostomy site ${ }^{8}$. In a study with 576 rectal cancer survivors, it was showed a frequent report of depression among rectal cancer survivors, especially in permanent ostomy patients, being associated with a financial expense increase. The overall prevalence of depression was $24 \%$ among rectal cancer survivors with the highest prevalence among those with a previous permanent ostomy $(31 \%)^{7}$. The patient disease perception and coping influence the QOL and health due to self-efficacy, anxiety and depression ${ }^{6}$. Poor disease perception is related to increased anxiety, depression and reduced health - QOL, specifically by affecting sexuality and self-body image, social function and functional capacity, stomatal function and financial concerns $^{26}$. A study with 500 inflammatory bowel disease patients (12.3\% underwent ostomy) four factorial profiles were identified through exploratory factor analysis: somaticaffective, low self-esteem, suicidal and anhedonia. It was also identified that inflammatory markers and disease activity are significant predictors of somatic-affective symptoms and anhedonia ${ }^{27}$. In addition to this symptomatic profile categorization, it is possible to suggest that psychological distress can have a clinically relevant impact on wound healing, and depression is also associated with the healing impairment ${ }^{28}$. Therefore, we may suggest that this decrease in quality of life in ostomized patients may be a possible explanation for the depressive symptoms observed in the present study.

In the present study, we found no cortisol level alterations in ostomy patients when compared to health control group. Cortisol is secreted in response to stress and playing a key role by maintaining the body's blood pressure, immune function and anti-inflammatory processes ${ }^{29}$. The damage may occur when there is continuous or long-term stress exposure, resulting in continued cortisol production, leading to higher cortisol levels, which is a MDD risk ${ }^{30}$. Although, cortisol level alterations is not a diagnostic exam for MDD, but is a marker for hypothalamus-pituitary-adrenal (HPA) alteration ${ }^{31}$. Therefore, despite ostomy patients have depressive symptoms, seems that they not show HPA alteration.

The present study demonstrated an increase in depressive symptoms in ostomized patients when compared to healthy controls, accompanied by alterations in neurotrophins. Depression has been associated with disturbances in structural and synaptic plasticity ${ }^{10}$. Neurotrophic factors mediate several cellular functions through the receptor activation, including the gene expression that are integrally involved in the neuroplasticity regulation and cellular health. Most neurotrophin functions are mediating by the tropomyosin-related receptor tyrosine kinase $(T r k)^{21}$. Studies have suggested that depressive mood results from the brain's inability to making appropriate adaptive responses to environmental stimuli as result of synaptic plasticity and impaired structural plasticity ${ }^{32}$.

The present study showed a BDNF decrease and NT-3 increase levels in serum from ostomy patients when compared to healthy controls. Several studies suggest that BDNF is involved in depression ${ }^{33,34}$. Previous study showed that depressed patients present decreased BDNF expression, and antidepressants up-regulate the BDNF expression ${ }^{35}$. It is well described that depressed patients have alterations in BDNF expression in blood cells ${ }^{35-37}$. Also, Ozan et al. ${ }^{36}$ demonstrated that patients with MDD had a lower BDNF level in serum when compared to healthy control. In another study with 112 women post-treatment breast cancer survivors, the author evaluated depressive symptoms persist after the treatment completion and the Met allele of the BDNF Val66met polymorphism, suggesting these changes were activated via inflammatory processes arising from the treatment. Thus, BDNF Met allele could be a risk and vulnerability factor for inflammation-induced depression ${ }^{38}$. Suggesting an important role of inflammation in both depressive symptoms and changes in BDNF in this present study.

Hock et al. ${ }^{39}$ used cerebrospinal fluid from elderly MDD patients, and compared to Alzheimer's disease ones, and mentally healthy control subjects. The results showed that NT-3 had a significantly increase in MDD patients than Alzheimer's disease patients and controls, suggesting that NT-3 increase may indicate a disturbance of the central noradrenergic system in these MDD patients. In another study, in drug-free subjects with bipolar disorder during manic and depressive episodes, the author showed increased in NT-340. Further research is needed to better understanding this possible negative correlation between both neurotrophins.

In present study, the results did not demonstrate significant differences in NGF levels in serum from ostomy 
and control group. In a previous study, Kheirouri et al. ${ }^{41}$ measure serum levels of BDNF and NGF in patients in first MDD episode compared to health controls. Their results showed BDNF decrease in depressive patients, and did not significant differences in NGF levels; NGF levels were not associated with stress, severity, or duration of the depressive episode.

\section{CONCLUSION}

In conclusion, the present study suggests ostomy triggers depressive symptoms and alterations in neurotrophins observed in blood collected from these patients.

\section{INDIVIDUAL CONTRIBUTIONS}

Valvassori, Schwalm, Ceretta and Jornada designed the study and wrote the protocol. Bavaresco, Rosa and Schwalm, managed the literature searches and analyses. Quadros, Zimmermann and Simon undertook the experimental procedures, biochemical and statistical analysis. Bavaresco and Quadros wrote the first draft of the manuscript. All authors contributed to and have approved the final manuscript.

\section{CONFLICT OF INTEREST}

The present study has no conflict of interest.

\section{ACKNOWLEDGEMENTS}

We thank CNPq, Fapesc, Capes and Unesc for financial support.

\section{REFERENCES}

1. Beck DE, Nasseri Y, Hull TL, Roberts PL, Saclarides TJ, Senagore AJ, et al. Manual of colon and rectal surgery. New York: American Society of Colon and Rectal Surgeons; 2014.

2. Burch J. Exploring quality of life for stoma patients living in the community. Br J Community Nurs. 2016;21(8):378-82.

3. United Ostomy Associations of America, Inc. Homepage: http://www.ostomy.org/Home. html.

4. Sier MF, Oostenbroek RJ, Dijkgraaf MGW, Veldink GJ, Bemelman WA, Pronk A, et al.; iAID study group. Home visits as part of a new care pathway (iAID) to improve quality of care and quality of life in ostomy patients: a cluster-randomized stepped-wedge trial. Colorectal Dis. 2017;19(8):739-49.

5. Richbourg L, Thorpe JM, Rapp CG. Difficulties experienced by the ostomate after hospital discharge. J Wound Ostomy Continence Nurs. 2007;34(1):70-9

6. Knowles SR, Tribbick D, Connell WR, Castle D, Salzberg M, Kamm MA. Exploration of Health Status, Illness Perceptions, Coping Strategies, Psychological Morbidity, and Quality of Life in Individuals With Fecal Ostomies. J Wound Ostomy Continence Nurs. 2017;44(1):69-73.
7. Chongpison Y, Hornbrook MC, Harris RB, Herrinton LJ, Gerald JK, Grant M, et al. Self-reported depression and perceived financial burden among long-term rectal cancer survivors. Psychooncology. 2016;25(11):1350-6.

8. Anaraki F, Vafaie M, Behboo R, Maghsoodi N, Esmaeilpour S, Safaee A. Quality of life outcomes in patients living with stoma. Indian J Palliat Care. 2012;18(3):176-80.

9. Hong KS, Oh BY, Kim EJ, Chung SS, Kim KH, Lee RA. Psychological attitude to self-appraisal of stoma patients: prospective observation of stoma duration effect to self-appraisal. Ann Surg Treat Res. 2014;86(3):152-60.

10. Duman RS, Malberg J, Nakagawa S, D'Sa C. Neuronal plasticity and survival in mood disorders. Biol Psychiatry. 2000;48(8):732-9.

11. Caviedes A, Lafourcade C, Soto C, Wyneken U. BDNF/NF-kB signaling in the neurobiology of depression. Curr Pharm Des. 2017;23(21):3154-63.

12. Chiou YJ, Huang TL. Serum brain-derived neurotrophic factors in Taiwanese patients with drug-naïve first-episode major depressive disorder: effects of antidepressants. Int J Neuropsychopharmacol. 2016;20(30):213-8.

13. Meewisse ML, Reitsma JB, de Vries GJ, Gersons BP, OlffM. Cortisol and post-traumatic stress disorder in adults: systematic review and meta-analysis. Br J Psychiatry. 2007;191:387-92.

14. Quervain DJ de. Glucocorticoid-induced reduction of traumatic memories: implications for the treatment of PTSD. Prog Brain Res. 2008;167:239-47.

15. Volko CD, Regidor PA, Rohr UD. Model approach for stress induced steroidal hormone cascade changes in severe mental diseases. Horm Mol Biol Clin Investig. 2016;25(3):157-70.

16. Rubin de Celis MF, Bornstein SR, Androutsellis-Theotokis A, Andoniadou CL, Licinio J, Wong ML, et al. The effects of stress on brain and adrenal stem cells. Mol Psychiatry. 2016;21(5):590-3.

17. Van Rossum EF, Binder EB, Majer M, Koper JW, Ising M, Modell S, et al. Polymorphisms of the glucocorticoid receptor gene and major depression. Biol Psychiatry. 2006;59(8):681-8.

18. Allen SJ, Watson JJ, Shoemark DK, Barua NU, Patel NK. GDNF, NGF and BDNF as therapeutic options for neurodegeneration. Pharmacol Ther. 2013;138(2):155-75.

19. Barde YA. The nerve growth factor family. Prog Growth Factor Res. 1990;2(4):237-48

20. Autry AE, Monteggia LM. Brain-derived neurotrophic factor and neuropsychiatric disorders. Pharmacol Rev. 2012;64(2):238-58

21. Dwivedi Y. Brain-derived neurotrophic factor: role in depression and suicide. Neuropsychiatr Dis Treat. 2009:5:433-49.

22. Bocchio-Chiavetto L, Bagnardi V, Zanardini R, Molteni R, Nielsen MG, Placentino A, et al. Serum and plasma BDNFlevels in major depression: a replication study and meta-analyses. World J Biol Psychiatry. 2010;11(6):763-73.

23. Dell'Osso L, Del Debbio A, Veltri A, Bianchi C, Roncaglia I, Carlini M, et al. Associations between brain-derived neurotrophic factor plasma levels and severity of the illness, recurrence and symptoms in depressed patients. Neuropsychobiology. 2010;62(4):207-12.

24. Lowry OH, Rosebrough NJ, Farr AL, Randall RJ. Protein measurement with the Folin phenol reagent. J Biol Chem. 1951;193(1):265-75

25. Wiglusz MS, Landowski J, Michalak L, Cubała WJ. Symptom Frequency Characteristics of the Hamilton Depression Rating Scale of Major Depressive Disorder in Epilepsy. Psychiatr Danub. 2015;27 Suppl 1:S227-30.

26. Knowles SR, Wilson J, Wilkinson A, Connell W, Salzberg M, Castle D, et al. Psychological well-being and quality of life in Crohn's disease patients with an ostomy: a preliminary investigation. J Wound Ostomy Continence Nurs. 2013;40(6):623-9.

27. Levine A, Keljo D, DeMaso D, Bousvaros A, Szigethy E. 0-017 YI inflammatory versus noninflammatory predictors of specific depressive symptoms in a large pediatric cohort with IBD. Inflamm Bowel Dis. 2016:22:1-6

28. House SL. Psychological distress and its impact on wound healing: an integrative review. J Wound Ostomy Continence Nurs. 2015;42(1):38-41.

29. Herbert J. Cortisol and depression: three questions for psychiatry. Psychol Med. 2013:43(3):449-69

30. Valassi E, Crespo I, Keevil BG, Aulinas A, Urgell E, Santos A, et al. Affective alterations in patients with Cushing's syndrome in remission are associated with decreased BDNF and cortisone levels. Eur J Endocrinol. 2017;176(2):221-31.

31. Spencer RL, Deak T. A users guide to HPA axis research. Physiol Behav. 2017;178:43-65.

32. Fossati P, Radtchenko A, Boyer P. Neuroplasticity: from MRI to depressive symptoms. Eur Neuropsychopharmacol. 2004;14 Suppl 5:S503-10 
33. Wagner S, Kayser S, Engelmann J, Schlicht KF, Dreimüller N, Tüscher 0, et al. Plasma brainderived neurotrophic factor (pBDNF) and executive dysfunctions in patients with Major Depressive Disorder. World J Biol Psychiatry. 2018:1-38.

34. Busch Y, Menke A. Blood-based biomarkers predicting response to antidepressants. J Neural Transm (Vienna). 2018.

35. Grunebaum MF, Ellis SP, Keilp JG, Moitra VK, Cooper TB, Marver JE, et al. Ketamine versus midazolam in bipolar depression with suicidal thoughts: A pilot midazolam-controlled randomized clinical trial. Bipolar Disord. 2017;18(3):176-83.

36. Ozan E, Okur H, Eker C, Eker OD, Gönül AS, Akarsu N. The effect of depression, BDNF gene val66met polymorphism and gender on serum BDNF levels. Brain Res Bull. 2010;81(1):61-5.

37. de Azevedo Cardoso T, Mondin TC, Wiener CD, Marques MB, Fucolo Bde Á, Pinheiro RT, et al. Neurotrophic factors, clinical features and gender differences in depression. Neurochem Res. 2014;39(8):1571-8.
38. Dooley LN, Ganz PA, Cole SW, Crespi CM, Bower JE. Val66Met BDNF polymorphism as a vulnerability factor for inflammation-associated depressive symptoms in women with breast cancer. J Affect Disord. 2016;197:43-50.

39. Hock C, Heese K, Müller-Spahn F, Huber P, Riesen W, Nitsch RM, et al. Increased cerebrospinal fluid levels of neurotrophin 3 (NT-3) in elderly patients with major depression. Mol Psychiatry. 2000;5(5):510-3.

40. Fernandes BS, Gama CS, Walz JC, Ceresér KM, Fries GR, Colpo G, et al. Increased neurotrophin-3 in drug-free subjects with bipolar disorder during manic and depressive episodes. J Psychiatr Res. 2010;44(9):561-5.

41. Kheirouri S, Noorazar SG, Alizadeh M, Dana-Alamdari L. Elevated brain-derived neurotrophic factor correlates negatively with severity and duration of major depressive episodes. Cogn Behav Neurol. 2016;29(1):24-31. 